\title{
Turkish Language Teacher Metaphors of Pre-service Teachers According to Their Perceptions
}

\author{
Mehmet Fatih Özcan* \\ Department of Turkish and Social Sciences Education, AGRI IBRAHIM CECEN University, Turkey
}

Corresponding Author: Mehmet Fatih Özcan, E-mail: mefo3@hotmail.com

\section{ARTICLE INFO}

Article history

Received: September 15, 2019

Accepted: November 17, 2019

Published: December 31, 2019

Volume: 10 Issue: 6

Advance access: December, 2019

Conflicts of interest: None

Funding: None

Key words:

Teacher,

Turkish Language Teacher,

Metaphor

\begin{abstract}
The aim of this study is to determine the pre-service teachers' perceptions related to teacher / Turkish language teacher concepts through metaphors. The study group consists of first and fourth grade undergraduate students from Department of Turkish Language Teaching of Faculty of Education of Ağrı province and graduate students from Turkish Language Education in 2018-2019 academic years. The research data was collected with open ended questions. With the questions as "How do you think the concept teacher can be expressed with different words? Why?" related to teacher concept, "What is the first reaction and the first sentence you hear from the people when you tell them that you are a Turkish language teacher/study in the department of Turkish Language Teaching?" related to Turkish language teacher concept, and "What are the three words that you think of when Turkish language teacher is mentioned?" related to Turkish language teacher concept, preferability levels of the metaphors were determined with frequency, percentage, arithmetic mean and standard deviation; and t test was used to determine the difference between gender and views of the participants according to grade. According to the results obtained from the study, it was determined that the participants presented both positive and negative metaphors related to the questions. While a high number of positive metaphors such as educator / instructor, leading / guide / leader and father / mother, compassion, laborer, friend, honest, self-sacrificing, hope are produced, negative metaphors such as Hope killer / hangman and expropriator are also produced. Of the metaphors produced about the Turkish language teacher, the first four came out as silver-tongued/ calligraphic, grammar, book and poet / poem. In addition, metaphors like Unemployed and With Poor Turkish/Short-tempered were also produced.
\end{abstract}

\section{INTRODUCTION}

The concept of qualified work force and teacher emerges as the most basic concept of both the 21 st century and education systems. In determining educational policies, the place of the teaching profession in this context should not be ignored. In the comparison of international education systems, it has been determined that the success rates of the countries with qualified teachers are higher than the others. The active interaction of teachers with all elements contributes directly to student success while determining the quality of education and society. Balc1 (1991) defined the concept of "teacher" mentioned above as "Teacher is a learning tool, examiner, maintains discipline, advocate of middle class morality and proxy. The teacher is the trusted person, the substitute parent, student advisor, colleague and community participant. These are the images given to the teacher in relation to his profession."; Özden (2002) defined it as "The architects of a country's future are teachers. Teachers are the one who trains engineers, doctors, lawyers, teachers, soldiers, police, chauffeur, in short, those who serve in all parts of the society. Teachers play very important roles in the fates of countries."; Çelikten (2006) defined it as "The quality of the new generations will undoubtedly be identical with the quality of the teachers who train them. After all - the teacher is the farmer who reaps the harves the latest- byword reveals this fact quite well. In short, the teacher is the human architect, an artist who shapes the personality of the human being."

Sufficient number of teachers in schools is not the only factor determining the quality of teaching. Based on the definitions of Balc1, Özden and Çelikten, it can be said that the training of preservice teachers as talented, loving their profession, aware of the expectations and striving will be the most important factor determining the quality of teaching.

When the structure of the language, the forms of formation and the ways of derivation of the word are examined, it is more economical to reinterpret the existing words by adapting them to the situation and the event, instead of producing words from scratch for the situations that occur in the direction of social development. We can call this reinterpretation with the concepts of metaphor or with Demirci's (2016: 330) definition with the terms "analogy, or similitude, an old saying."Şahin (2017:87) describes the metaphor as "a mental and linguistic product that is produced as a result of an effort to make the unknown known and recognizable by resembling something that our mind does not know or cannot fully explain to something else that it knows and 
can fully comprehend. When the metaphor definitions are analyzed, it is seen that the word metaphor contains many meanings in terms of its structure. This diversity arises from the fact that metaphor expresses words with the task of "carrying meaning" without limiting the meaning.

In the Great Turkish Dictionary of TDK which is ppen to access online, the concept "metaphor is expressed as Fr. métaphore a. ed. Mecaz." (Http://tdkterim.gov.tr). Metaphor is derived from Greek Metapherein "or" Metaphora "roots. "Meta" means change and "pherein" means overflow (Levine, 2005). We can define themeaning of the word "mecaz" as using a word or concept outside the real meaning as a result of analogy. While the concept of mecaz is used for "metaphor", other words such as "analogy, figure of speech, borrowing, idiom transfer "are also used. Altun (2003: 3) uses the word "metaphor" instead of the concept of figure of speech, and he explained this as "figure of speech is to use one word instead of another for the purpose of analogy. This art has both metaphor and analogy features. The figure of speech (metaphor) must have three qualities:

1. Use of the word outside its real meaning,

2. Carrying the purpose of analogy,

3. A situation that prevents the real use of the word".

According to Lakoff and Johnson (2005), metaphor is understanding and experiencing something from another point of view and is the process of expressing a material of thought in a form of human comprehension. The metaphor is not only a word figure but also a thought figure. "In the book named "Yabancı Kelimelere Karşılıklar" (2002), metaphor is defined as métaphore (metaphor) from French.

"Metaphors describe how people perceive the world, objects, events, movements, and so on. is a clear expression of what they think about. "(Kemal, 2003: 1).

When looking at the studies of researchers interested in Turkish rhetoric, it is seen that terms such as idiom transfer, figure of speech, similitude are used in acknowledgement of metaphor, and explanations about metaphor are made within the framework of these terms (Bilgegil, 1989, Erdem, 2003, Kemal, 2003, Aksan, 2006, Coşkun, 2007).

A binary structure is sufficient to from a metaphor. The existence of the two sides is sufficient for the metaphor as long as there is a common feature that can establish a similarity, whether strong or weak. Nevertheless, it is common to compare the lesser to the more common in metaphors (Crystal 2008: 98). The aim of metaphorical narrative is not to simply say something as it is, but to express it in a way that leaves a mark and leads to a certain effect (Porzig, 1995). In summary, the metaphor can also be called the analogy of the new to the old. Metaphors make it easier to teach what is unknown or difficult to learn. In memory techniques books, words or concepts are taught by associating them with a different concept or creating a story. Because learning is provided by pasting new information into the schemas that exist in minds.

\section{Problem}

What are the opinions of preservice teachers about the teacher / Turkish language teacher metaphors?

\section{Sub-problems}

1. The sub-problems of the study are as following: "How do you think the concept of 'teacher' can be expressed in different words? Why?",

2. "What is the first reaction and the first sentence you hear from the people when you tell them that you are a Turkish language teacher/study in the department of Turkish Language Teaching?"

3. "Write the first three words that come to your mind when Turkish language teacher is mentioned".

\section{METHOD}

\section{Research Design}

In the study, the qualitative research method, which allows us to provide a realistic and holistic way of presenting perceptions and events and forming the basis of in-depth analysis, was used to determine the metaphors that students formed to express their thoughts on the concept of teacher. Phenomenology design was adopted in the study. The purpose of the phenomenology design is to reveal the individuals' experiences, perceptions related to an event and the meanings attributed to them by individuals. "Data analysis is intended to reveal experiences and meanings in phenomenology studies. In the content analysis conducted for this purpose, there is an effort to conceptualize the data and to reveal the themes that can define the phenomenon. The results are presented in a descriptive way and often include direct quotations. In addition, the findings obtained within the framework of themes and patterns are explained and interpreted" (Yıldırım \& Şimşek, 2011: 72). At the end of the study, the concepts created by the students and the questions they answered were examined and the ones except for those which were not suitable for the purpose and were not clearly answered were coded and categories were formed. The findings were expressed as frequency and percentage. The number and percentages of the participants were also calculated.

\section{Study Group}

The study group of the study consists of 90 undergraduate students of $1 \mathrm{st}, 3 \mathrm{rd}$, and 4th grade and 10 graduate students from the Department of Turkish Language Education of the Faculty of Education of Ağrı İbrahim Çeçen University in 2018-2019 academic year.

\section{Data Collection Tool}

The study consists of three sub-problem sentences. Therefore, the question that expresses each sub-problem sentence was directed to the participants and the data were collected.

When Table 1 is examined, the total number of participants participating in our study is 100 . It is seen that these participants are mostly in the $23+$ age group. This age group is followed by the age of 22 with 26 people. The fact that 22 and $23+$ age groups coincided with the 3 rd and 4 th grades helped the answers to the question of "What are the opinions of the preservice teachers about the teacher / Turkish language teacher metaphors?", which is the problem statement of our study, to be more deliberative. 
In the data collection part of the study, national and international researches were examined to determine the metaphors. In addition, articles, master's and doctoral theses in which the concept of teacher was explained were examined. In determining the concept of metaphor, it was seen that open-ended questions were asked, and answers were sought. Regarding the concept of teacher starting from its historical development, questionnaire, open-ended question and interview methods were chosen for the opinions of students, teachers, administrators and parents. In accordance with the purpose of our research, 10 expert opinions were taken in terms of clarity of the questions, their being answerable and so on. In line with these views, the form was finalized, and the application period was planned. Accordingly, in order to reveal the perceptions of the students participating in the research regarding the concept of "Teacher and Turkish Language Teacher", a form on which "How do you think the concept teacher can be expressed with different words?" Why?", "What is the first reaction and the first sentence you hear from the people when you tell them that you are a Turkish language teacher/study in the department of Turkish Language Teaching?" and "Write the three words that you think of when Turkish language teacher is mentioned?" was given to each of the participants. Before the implementation, the concept of metaphor was explained, and a few examples were given in order to make sense of meaning and they were asked to state their perceptions about the questions in the form. They were given a 25-minute application time.

\section{FINDINGS}

In this section, the findings obtained according to the sub-problems are presented.

Table 1. Findings related to the personal characteristics of the participants

\begin{tabular}{lccccc}
\hline Gender & \multicolumn{4}{c}{ Age } & Total \\
\hline & -20 & 21 & 22 & $23+$ & \\
Male & 5 & 10 & 11 & 21 & 47 \\
Female & 10 & 11 & 15 & 17 & 53 \\
Total & 15 & 21 & 26 & 38 & 100 \\
\hline
\end{tabular}

10 of the answers given to the first sub-problem of the study "How do you think the concept teacher can be expressed with different words?" Why?" were excluded as they didn't reflect our aim. 104 answers were handled as the basic source data of the study.

When the Table 2 is analyzed, it can be seen that a total of 104 concepts was determined related to the concept of "teacher" as a preservice teacher. The fact that the number is high shows that the preservice teachers developed a rich point of view related to the concept of "teacher." It can be seen in Table 2 that metaphors like Educator/Instructor, Conductor/Guide/Leader and Father/Mother were produced in high numbers. The total number of these metaphors is 56 . This constitutes $53,22 \%$ of the question. Among the metaphors created, "family" was used 5 times, "mercy, laborer, friend, honest, self-sacrificing, hope" were used 3 times, "everything that is beautiful, poet and candle" were used twice, "cool, maestro, comrade of the long-distance, life itself, patient, beyond expression, scorer, shepherd, harbor, earth, light, director and the walking dictionary" were used once. The metaphors "hope-killer/hangman" that we can describe as negative except for these were used twice. With reference to the metaphors created, it can be said that the metaphors created related to the concept of the teacher starting with educator/ instructor and following conductor, family, mother/father and friend concepts mean that this concept indicates a warm color on the preservice teachers' mind. The metaphors "everything that is beautiful" and "life itsel" indicate the sanctity of this profession. The other two striking negative metaphors are "hope-killer/hangman" and "expropriator" concepts. Considering the concept of teaching profession, it can be said that defining teaching profession as such is upsetting.

Some answers to the question "How do you think the concept teacher can be expressed with different words?" Why?" are as following:

T1: We can express it as conductor, leader. Because a teacher is like a spotlight and enlightens his environment.

T2: Teaching profession is the noblest profession. The one who practices this profession is the director of the world. Because a teacher can change the world if $\mathrm{s} / \mathrm{he}$ wants. If the world is made up of humans, individuals cannot do without a teacher.

Table 2. The answers to the question "how do you think the concept teacher can be expressed with different words?" Why?"

\begin{tabular}{lcc}
\hline Concept & Frequency value & Percentage \\
\hline Educator / Instructor / Tutor & 23 & 21,5 \\
Conductor / Guide / Leader & 19 & 18,26 \\
Father / Mother & 14 & 13,46 \\
Family & 5 & 4,80 \\
Mercy, Laborer, Friend, Honest, Self-sacrifying, Hope & $3(18)$ & 17,30 \\
Sculptor, Everything that is Beautiful, Poet, Candle & $2(8)$ & 7,69 \\
Cool, Maestro, Comrade of the Long-Distance, Life Itself, Patient, Beyond Expression, Scorer, & $1(13)$ & 12,5 \\
Shepherd, Harbor, Earth, Light, Director, Walking Dictionary & 2 & 1,92 \\
Hope-Killer / Hangman & 2 & 1,92 \\
Expropriator & 104 \\
Total & 2 \\
\hline
\end{tabular}


T3: If I was up to me, it would be inappropriate to express it with other words. Because I wouldn't find a better, more meaningful word apart from "teacher" if it took my years to think.

T4: Teaching profession is a voluntary thing.

T5: S/he must be a poet who adds up passion and love to the subject $\mathrm{s} / \mathrm{he}$ is going to teach with his/her colorful and magic tongue.

T6: The reason for being for tomorrow.

T7: Have a full knowledge of everything, the one who knows everything

T8: Being teacher is to be the language of the students who cannot talk, to have lots of children.

T9: A maestro: combines different beauties with equal love and support.

T10: A teacher is the painter who paints the student canvas.

T11: S/he is the shepherd of the sheep.

Ö12: I made the definition of "mother/father" because we spend the most important times of our lives with our teachers.

T13: A guide, because s/he guides us. A friend, because s/he listens to us.

T14: A candle. Because s/he enlightens the dark.

T15: The teacher concept can be expressed with the life concept. Because s/he does not just train children for the future but educates the life. Of course, this differs from

Table 3. Frequency values

\begin{tabular}{|c|c|c|}
\hline Name of the Metaphor & $\begin{array}{l}\text { Frequency } \\
\text { value }\end{array}$ & Percentage \\
\hline Silver-tongued/calligraphic & 34 & 24,28 \\
\hline Grammar & 28 & 20 \\
\hline Book & 15 & 10,71 \\
\hline Poem/poet & 13 & 9,28 \\
\hline Novel/story & 6 & $4,28(\mathrm{x} 2)$ \\
\hline Dictionary & 6 & \\
\hline My future/ dream & 4 & $2,85(x 3)$ \\
\hline Mercy & 4 & \\
\hline Cultured/ respectful/ virtuous & 4 & \\
\hline Love & 3 & 2,14 \\
\hline Mother/father & 2 & $1,66(\mathrm{x} 12)$ \\
\hline Teaching/understanding easily & 2 & \\
\hline Paragraph & 2 & \\
\hline Veteran/self-sacrificing & 2 & \\
\hline Cool & 2 & \\
\hline Future/hope & 2 & \\
\hline Art & 2 & \\
\hline Intelligent/ hardworking & 2 & \\
\hline Naive & 1 & $0,71(\mathrm{x} 3)$ \\
\hline Atatürk & 1 & \\
\hline Best-loved & 1 & \\
\hline Unemployed & 2 & $1,42(x 2)$ \\
\hline With bad Turkish /Short-tempered & 2 & \\
\hline Total & 140 & 100 \\
\hline
\end{tabular}

one teacher to another; some take the divine light of the life, some give the divine light to life and become the divine light.

T16: The one who changes the life, trains humans.

There is a total of 140 metaphors related to the answers to the sub-problem "Write the three words that you think of when Turkish language teacher is mentioned?", and the frequency and percentage distributions are indicated on Table 3.

In the first four row of the answers related to the concept of "Turkish language teacher" are the silver-tongued/ calligraphic, grammar, book and poet/poem. These four metaphors, in fact, summarize the Turkish language teacher concept briefly. When we look at the other metaphors, it is seen that "love, mercy, naïve, respectful" concepts which every individual should have and are inevitable characteristics for a teacher were used initially. The metaphors "future/hope, my future/dream" is a good proof how the Turkish language teaching has a place in the students' mind. "Mother/father" metaphors indicate the love and respect for the teachers. Although there are the good metaphors related to Turkish language teaching, the metaphors "unemployed and with

Table 4. The answers to the question " $\mathrm{i}$ am a turkish language teacher/ study in turkish language teaching"

\begin{tabular}{lcc}
\hline Metaphor & $\begin{array}{c}\text { Frequency } \\
\text { value }\end{array}$ & Percentage \\
\hline $\begin{array}{l}\text { Can you get appointed? How } \\
\text { many are appointed? }\end{array}$ & 46 & 32,39 \\
Good department & 27 & 19,01 \\
You won't get appointed & 12 & 8,454 \\
How good it is that you teach our & 12 & 8,45 \\
mother tongue & & \\
Wasn't there any other & 9 & 6,33 \\
department? & & \\
Do you read books? & 9 & 6,33 \\
You have a gift for gab/ do you? & 8 & 5,63 \\
How can that be written? & 3 & 2,11 \\
Ağr is bad city, the university & 2 & 1,40 \\
must be so. & & \\
How do you like grammar & 2 & 1,40 \\
God help you! & 2 & 1,40 \\
You study in vain & 1 & 0,70 \\
Is it difficult? & 1 & 0,70 \\
Are you patient? & 1 & \\
You're very lucky! & 1 & \\
How much is your wage? & 1 & \\
You must read poems very well/ & 1 & \\
are you a good poet/writer? & & \\
You're doctor of verbal fields. & 1 & \\
Turkish language teachers are & & \\
masters & & \\
It's a cool department & & \\
You can't even speak Turkish & & \\
and you're studying it! & Total & \\
\hline
\end{tabular}


bad Turkish/short tempered" are the other side of the coin. These negative words are seen in the third question of the questionnaire applied to the students.

The answers to the last of the sub-problems "What is the first reaction and the first sentence you hear from the people when you tell them that you are a Turkish language teacher/ study in the department of Turkish Language Teaching?" are indicated on Table 4.

"Unemployment/appointment" problem mentioned in the second section comes the first in the answers to the question "What is the first reaction and the first sentence you hear from the people when you tell them that you are a Turkish language teacher/study in the department of Turkish Language Teaching?" This unfortunately pushes both students and their families into pessimism. "You won't get appointed" metaphor follows this negative thought in the $3^{\text {rd }}$ row. The concept "wasn't there any other department" emerged as an answer because of appointment problem. In addition to these negativities, such an answer "You can't even speak Turkish and you're studying Turkish language teaching!" based on student indicates that it is a critical problem for teaching profession, particularly for Turkish language teaching.

\section{CONCLUSION AND RECOMMENDATIONS}

We can refer to the importance of teaching profession which constitutes the purpose of our study by Changing the saying of Nietzsche $(2016,37)$ "People are born, grow, live and die. It's not important to live but to do more as long as you live" into "people exist, born, grow and die. People exist and born, grow but not die. They live with their works and services in the hearts of others. You see, the duty of the teacher is to train those who live even though they are dead." In order for societies to raise individuals with the concept of value, the teacher in the position of instructor must be at the highest level perceptively in the society. For this purpose, the metaphor study we have conducted with preservice teachers who will be teachers of the future on "teacher" has positive feedback. At the end of the study, we also observed the perception of the concept of Turkish language teacher in the society. Metaphors like educator/ instructor, conductor/ guide / leader and father / mother that express the concept help students to access and use information, and while helping, creating parental warmth and family environment are among the expected. With the metaphors like "sculpture" etc., it can be thought that the teacher is perceived as the one who "seals student's fate" somewhat.

As a result, an analysis was made by determining the meanings attributed by the preservice teachers to the teacher/ Turkish language teacher by means of metaphors and it was seen that most of the preferred metaphors had positive meaning. With reference to the negative ones such as "hope-killer/ hangman, expropriator", this and similar perceptions and behaviors should be corrected considering the primary duty of the teacher. The emergence of the term "unemployed" for the Turkish language teacher indicates that despair is at the forefront. States should arrange teacher appointments in a way that will make people happy and hopeful. The fact that the metaphor "you won't get appointed" was in high rate as a social perception in the "teacher/Turkish language teacher" section supports our view on despair. Based on the answers given by the age groups, we see that $1^{\text {st }}$ and $2^{\text {nd }}$ grade students are more optimistic about the appointment.

It is accepted by almost everyone in Turkey that teaching profession is a "sanctified profession." That is, cultural respect for teachers has always existed from past to present. However, it has recently been concluded that respect for teachers has diminished. The lack of appointment of preservice teachers, the increase in violence against teachers, and the questioning of the workloads and the wages they receive by the community and government officials confirm this situation. On the other hand, although respect for the profession has diminished, teaching is still one of the most trusted occupational groups in society. In a study conducted in 2010, it was determined that teaching is the most trusted professions in Turkey (GFK Türkiye, 2010). That the preservice teachers also define themselves as "with bad Turkish/short-tempered" is important in terms of both making self-criticism and being aware of this negativity. It is always more important to be aware of the problem than the problem. In addition, it is necessary to make a situation analysis with the teachers, students, parents and administrators about the negative metaphors resulting from this study, to measure mutual perceptions and to make them more useful tools for education. Various activities should be organized for this purpose. In particular, the negative thoughts of preservice teachers about their professions will also make their training inefficient. It will be hard to study in an unpopular, undesired department and to prepare for a profession in which it is difficult to be appointed and this is always mentioned. It is evident that these negative emotions brought from the past after their appointment will prevent them from giving the necessary sacrifice. In order to correct this negative perception, the authorities should be in constant interaction with teachers and necessary works should be done studiously.

\section{REFERENCES}

Altun, M. (2003). Edebi Sanatlar: Klasik edebiyat (belagat) bağlamında anlam. (http://www.dilbilimi.net/edebi sanatlar.pdf) (erişim tarihi: 11.05.2019)

Aksan, D. (2006). Anlambilim konuları ve Türkçe'nin anlambilimi. Ankara: Engin Yayınları.

Balc1, E. (1991). Öğretmenlerin rolleri, Eğitim Sosyolojisi, Ankara: Gazi Büro Kitabevi.

Balc1, A. (1999); MetaphoricalImages of School: School Perceptions of Students, Teachers and Parents from four Selected Schools (in Ankara). A Dissertation Submitted in Partial Fulfillment of The Requirements for The Degree of Doctor of Educational Science, Ankara: METU.

Bilgegil, M. K. (1989). Edebiyat bilgi ve teorileri: (Belagat). İstanbul: Enderun Kitabevi.

Crystal, D. (2008). A Dictionary of Linguistics and Phonetics, Oxford: Blackwell Publishers.

Çelikten, M. (2006). Kültür ve öğretmen metaforları. Erciyes Üniversitesi Sosyal Bilimler Enstitüsü Dergisi, 21(2), 269-283.

Coşkun, M. (2007). Sözün büyüsü edebi sanatlar. İstanbul: Dergâh Yayınları. 
Demirci, K. (2016). Metafor: Bir Anlatım Ve Üretim Mekanizmas1. Dil Bilimleri Kültür ve Edebiyat, (Edt. M Sarıca, B. Sarıca), Ankara: Padam Yayınları,

Erdem, M. (2003). Türkmen Türkçesi'nde metaforlar. Ankara: Köksav Yayınları.

Gfk Türkiye. (2010). Türkiye'de meslek gruplarına ve kurumlara güven azallyor.. http://www.gfk.com/imperia/ $\mathrm{md} /$ content/gfkturkiye/pressreleases/gfk_turkiye_guven_endeksi_basin_bulteni_haziran_2010.pdf (erişim tarihi: 01.06.2019)

Kemal, M. (2003). Budhist Türk çevresi eserlerinde metafor. Yayımlanmamış doktora tezi. Ankara Üniversitesi, Ankara.

Lakoff, G. ve Johnson, M. (2005). Metaforlar: Hayat, Anlam ve Dil (Çev: G.Y.Demir), İstanbul: Paradigma Yayınları.

Levine, P.M. (2005). MetaphorsandImages of Classrooms. ERIC: EJ724893.

Nietzsche, F. (2016). Aforizmalar. İstanbul: İlgi Kültür Sanat Yayınları.

Özden, Y. (2002). Ĕ̆itimde yeni değerler. Ankara: Pegem A Yayınc1lik.

Porzig, W. (1995). Dil denen mucize (V. Ülkü, Çev.). Ankara: TDK Yayınları.

Saban, A. (2004). Prospective classroom teachers' metaphorical images of selves and comparing them to those they have of their elemantery and cooperating teachers. International Journal of Educational Development, 24, 617-635.

Şahin, N. (2017). Dede Korkut Hikâyeleri'ndeki Metaforlar. Uluslararası Türkçe Edebiyat Kültür Eğitim Dergisi Sayl: 6/1 2017 s. 84-114.

Yıldırım, A. Şimşek, H. (2011). Sosyal Bilimlerde Nitel Araştırma Yöntemleri. Ankara: Seçkin Yayıncılık.
Atkinson, D., Churchill, E., Nishino, T., \& Okada, H. (2007). Alignment and interaction in a sociocognitve approach to second language acquisition. The Modern Language Journal, 91, 169-188.

Byrnes, H. (2012). Advanced language proficiency. In S.M. Gass \& A. Mackey (Eds.), The Routledge handbook of second language acquisition, (pp. 506-521). New York: Routledge.

Cogo, A., \& Dewey, M. (2012). Analyzing English as a lingua franca. London: Continuum.

Ellis, R. (2008). The study of second language acquisition ( $2^{\text {nd }}$ ed.). Oxford: Oxford University Press.

Hulstijn, J. H., Young, R. F., \& Ortega, L. (in press). Bridging the gap: Cognitive and social approaches to research in second language learning and teaching. Studies in Second Language Acquisition. doi:10.1017/ S0272263114000035.

O'Regan, J.P. (2014). English as a lingua franca: An immanent critique. Applied Linguistics, 1-21 [Advanced access published January, 2014].

Seidlhofer, B. (2010). Lingua franca English: The European context. In A. Kirkpatrick (Ed.), The Routledge handbook of world Englishes, (pp. 355-371). New York: Routledge.

Sert, O. (2013). (Un)willingness to participate as participants' concern: Reconsidering research on motivation in Applied Linguistics. Paper presented at the American Association for Applied Linguistics 2013 Conference, Dallas, Texas.

Strauss, A., \& Corbin, J. (1990). Basics of qualitative research: grounded theory procedures and techniques. Newbury Park, CA: Sage. 